\title{
GAMBARAN SPERMIOGRAM PENDERITA INFERTIL DENGAN VARIKOKEL
}

\author{
${ }^{1}$ Piere Tendean \\ ${ }^{2}$ Lydia Tendean \\ ${ }^{3}$ Benny Wantouw \\ ${ }^{1}$ Kandidat Skripsi Fakultas Kedokteran Universitas Sam Ratulangi Manado \\ ${ }^{2}$ Bagian Biologi Fakultas Kedokteran Universitas Sam Ratulangi Manado \\ Email: h4rd1_cool@yahoo.co.id
}

\begin{abstract}
Spermiogram is an examination for determination of male fertility. Evaluation of a spermiogram consists of macroscopical and microscopical examination of sperm cells, which are concentration, motility and morphology of sperm cells. This study aimed to obtain the spermiogram of infertile patients with varicocele. This was an observational study with a cross-sectional design by using sperm samples of 30 infertile patients with varicocele. Evaluation of spermatozoa quaity was determined by using WHO standard 2010. The results showed that the sperm concentrations were $<15 \mathrm{million} / \mathrm{ml}$, sperm motility $<40 \%$ /field, and sperm morphology $<30 \% /$ field. Conclusion: In this study the spermiogram of infertile patients with varicocele was abnormal with oligozoospermi, asthenozoospermi, and teratozoospermi.

Keywords: varicocele, spermiogram
\end{abstract}

\begin{abstract}
Abstrak: Spermiogram merupakan salah satu pemeriksaan untuk menentukan fertilitas seorang pria. Evaluasi spermiogram meliputi makroskopik dan mikroskopik sel spermatozoa yaitu konsentrasi, motilitas, dan morfologi sel spermatozoa. Penelitian ini bertujuan untuk mendapatkan gambaran spermiogram penderita infertil dengan varikokel. Penelitian ini bersifat observasional dengan desain potong lintang dengan menggunakan sampel sperma dari 30 penderita infertil dengan varikokel. Evaluasi kualitas spermatozoa berdasarkan standard WHO 2010. Hasil penelitian ini didapatkan yaitu konsentrasi sperma $<15$ juta/ml, motilitas sperma $<40 \% / l p$, dan morfologi sperma $<30 \% / l$. Simpulan: Pada penelitian ini gambaran spermiogram penderita infertil dengan varikokel ialah abnormal dengan oligozoospermi, asthenozoospermi, dan teratozoospermi.
\end{abstract}

Kata kunci: varikokel, spermiogram

Varikokel adalah gangguan pada vena skrotalis karena pelebaran pembuluh darah. Secara klinis dapat dibedakan atas varikokel primer dan varikokel sekunder. Varikokel merupakan suatu sindrom yang dapat menyebabkan kualitas sperma pria terganggu sehingga fertilitas pria akan terganggu sehingga terjadi infertilitas. ${ }^{4}$

Spermiogram merupakan salah satu pemeriksaan dalam menentukan fertilitas seorang pria. Beberapa pemeriksaan yang dievaluasi melalui spermiogram ialah secara makroskopik dan mikroskopik sel spermatozoa yaitu konsentrasi, motilitas, dan morfologi sel spermatozoa.

Kualitas sperma secara in vivo masih dapat dipengaruhi oleh keasaman vagina dan banyak faktor lain ketika spermatozoa tersebut masuk ke dalam sistem reproduksi wanita. Oleh karena itu perlu ditentukan kualitas spermatozoa secara in vitro, agar evaluasi kesuburan pria bukan hanya pada spermatozoa itu sendiri tetapi juga setelah sperma itu berada dalam leher 
Tendean, Tendean, Wantouw: Gambaran spermiogram penderita infertil ...

serviks agar interpretasi kualitas spermatozoa lebih akurat. ${ }^{5}$

Penelitian di bidang Kesehatan Reproduksi di Indonesia, belum ditemukan gambaran spermiogram penderita Varikokel dengan infertil di Sulawesi utara, sehingga melalui penelitian ini peneliti berkeinginan mengetahui gambaran spermiogram penderita varikokel dengan infertil di Sulawesi Utara.

\section{METODE PENELITIAN}

Penelitian ini merupakan penelitian observasional deskriptif dengan pendekatan potong lintang. Penelitian dilakukan selama 56 hari dari bulan November 2012 - Januari 2013, bertempat di Laboratorium Biologi Fakultas Kedokteran Universitas Sam Ratulangi. Variabel terdiri dari gambaran spermiogram penderita infertil dengan varikokel berumur 20 - 50 tahun.

\section{HASIL DAN BAHASAN}

Pada penelitian ini jumlah sampel sebanhyak 30 sampel sperma yang berasal dari 30 penderita infertil dengan varikokel,. Sampel dikeluarkan dengan cara onani dan diterima di laboratorium selambat-lambatnya setelah 30 menit. Kelompok sampel dibagi menjadi 3 kelompok masing-masing untuk melihat konsentrasi sperma, motilitas sperma dan morfologi sperma.

Berdasarkan standard WHO 2010, konsentrasi sperma normal bila jumlah sperma $\geq 15$ juta $/ \mathrm{ml}$; motilitas sperma normal bila motilitasnyæ 40\% /lp; dan morfologi sperma normal bila morfologi sperma lebih dari 30\%/lp.

Berdasarkan Tabel 1 dapat dilihat bahwa konsentrasi sperma $<5$ juta/ml terdapat 5 orang $(16,7 \%)$, konsentrasi sperma 5-10 juta/ml terdapat 7 orang $(23,3 \%)$ dan $>10$ juta/ml terdapat 18 orang (60\%). Hal ini menunjukkan bahwa rata-rata konsentrasi sperma dari penderita infertil dengan varikokel lebih kecil dari $60 \%$ atau disebut oligozoospermi.
Tabel 1. Deskripsi data berdasarkan konsentrasi sperma penderita infertil yang mengalami varikokel

\begin{tabular}{ccc}
\hline $\begin{array}{c}\text { Konsentrasi } \\
\text { Juta/ml }\end{array}$ & Jumlah & $\%$ \\
\hline $2-5$ & 5 & 16,7 \\
$6-10$ & 7 & 23,3 \\
$11-14$ & 18 & 60 \\
Total & 30 & 100 \\
\hline
\end{tabular}

Berdasarkan Tabel 2 dilihat bahwa motilitas sperma kurang dari 18\% sebanyak 7 orang (23,3\%), motilitas sperma $20-38 \%$ sebanyak 18 orang (60\%), dan $>38 \%$ sebanyak 5 orang $(16,7 \%)$. Hal ini menunjukkan bahwa tidak ada penderita yang memiliki motilitas sperma normal atau disebut asthenozoospermi.

Tabel 2. Deskripsi data berdasarkan motilitas pada penderita infertil yang mengalami varikokel

\begin{tabular}{ccc}
\hline Motilitas & Jumlah & $\%$ \\
\hline$<18 \%$ & 7 & 23,3 \\
$20-38 \%$ & 18 & 60 \\
$>38 \%$ & 5 & 17,7 \\
Total & 30 & 100 \\
\hline
\end{tabular}

Berdasarkan Tabel 3 dilihat bahwa morfologi sperma $<20 \%$ terdapat 1 orang (3,3\%), morfologi sperma 20-30\% terdapat 21 orang (70\%), dan $>30 \%$ terdapat 8 orang $(26,7 \%)$. Hal ini menunjukkan bahwa tidak ada yang memiliki morfologi sperma yang normal atau disebut teratoozospermi.

Tabel 3. Deskripsi data berdasarkan morfologi sperma pada penderita unfertil yang mengalami varikokel

\begin{tabular}{ccc}
\hline Morfologi & Jumlah & $\%$ \\
\hline$<20 \%$ & 1 & 3,3 \\
$20-30 \%$ & 21 & 70 \\
$>30 \%$ & 8 & 26,6 \\
\hline
\end{tabular}

\section{BAHASAN}

Pada deskripsi data penderita infertil dengan varikokel berdasarkan konsentrasi sperma didapatkan hasil terbanyak konsentrasi 11-14 juta/ml sebanyak 18 
orang (60\%) (Tabel 1). Hasil penelitian ini menunjukkan bahwa kebanyakan penderita tidak memiliki konsentrasi yang normal (bila konsentrasi $>15 \mathrm{juta} / \mathrm{ml}$ atau 40 juta secara keseluruhan). Jumlah $<15$ juta/ml disebut oligozoospermia, dan jika tidak ditemukan spermatozoa sama sekali disebut azoospermia. Varikokel menyebabkan inflamasi pada pembuluh darah testis yang membuat suhu testis meningkat sehingga jumlah sperma yang dihasilkan sedikit. ${ }^{14}$

Pada deskripsi data penderita infertil dengan varikokel berdasarkan motilitas sperma didapatkan hasil dari 30 penderita varikokel tidak ada yang memiliki motilitas sperma normal (Tabel 2). Sebanyak 21 penderita memiliki motilitas sperma $20-38 \%$ atau asthenozoospermi. Motilitas sperma disebut normal apabila dalam waktu 1 jam setelah ejakulasi, sebanyak $40 \%$ dari jumlah total spermatozoa yang masih hidup bergerak secara aktif. Varikokel dapat menyebabkan penderita mengalami infertil dengan memengaruhi spermatogenesis dan juga dapat mengakibatkan penurunan motilitas sperma. Hal ini mungkin disebabkan retensi darah pada varises, gangguan sirkulasi darah, kekurangan gizi dan tekanan parsial oksigen yang menurun sehingga mengakibatkan kekurangan energi dan disfungsi endokrin. ${ }^{15}$

Pada deskripsi data berdasarkan morfologi sperma, didapatkan hasil dari 30 penderita varikokel terdapat 21 penderita (70\%) yang memiliki morfologi 20-30\% (Tabel 3). Dari 30 penderita varikokel terdapat 25 penderita atau sekitar 83,3\% yang memiliki morfologi sperma abnormal atau disebut teratozoospermi. Dari 30 penderita yang mengalami varikokel terdapat morfologi abnormal bentuk kepala mikro sebanyak 25 orang $(83,3 \%)$ dan makro sebanyak 23 penderita $(76,6 \%) .{ }^{15}$

\section{SIMPULAN}

Dari hasil penelitian pada 30 penderita infertil yang mengalami varikokel dapat disimpulkan bahwa umumnya yang datang berobat ke klinik reproduksi berumur 20-40 tahun, sebagian dengan volume testis kiri telah mengecil akibat varikokel 17 orang dan testis kanan normal.

Pada penelitian ini gambaran spermiogram penderita infertil dengan varikokel ialah oligozoospermi, asthenozoospermi, dan teratozoospermi.

\section{SARAN}

1. Pada penderita infertil yang mengalami varikokel dengan gambaran spermiogram abnormal harus secepat mungkin diterapi agar memperoleh hasil yang maksimal.

2. Penderita varikokel perlu dilakukan pemeriksaan spermatozoa agar dapat secepat mungkin diobati.

\section{DAFTAR PUSTAKA}

1. Acosta AA, Kruger TF. Human Spermatozoa. In: Assisted Reproduction (2nd ed.). London: The Phartenon Publishing Group, 1996.

2. Centola GM, Ginsburg KA. Evaluation and Treatment of the Infertile Male. New York: Cambridge University Press, 1996.

3. Chan PTK. Varicocele and Male Infertility. In: Qian SZ, Baker HWG, editors. First Asian and Oceanic Congress of Andrology. Nanjing, 1992.

4. Comhaire FH. Varicocele. In: Serio $M$, Waites G, edeitors. Recent advance in an Andrology Serono Symposia Review No 20. Rome, 1989; p. 112-23.

5. Heidenberg HB. Varicocele Adolescent, Comment Problem on Infertility and Impotence. Raifer, editor. New York: Year Book Medical Publisher, 1990; p. 265-83.

6. Steeno O, Knoops J, Declerc L, Adimoelja A, van de Koorde. Prevention of Fertility Disorder by Detection and Treatment of Varicocele at school and College Age. Andrologia. 1976;8(1):47-53.

7. Tendean OS. Pencegahan dan Penanggulangan Varikokel serta perbaikan Infertilitasi dan Disfungsi Seksual dengan Pengobatan Vitamin E Anti Oksidan. Manado: Fakultas 
Kedokteran Unsrat, 1997.

8. Tendean OS. Effectivity Study of Tribestan on the Ability of Spermatozoa to live in Vitro. International Symposium on Reproduction, Infertility and Sexual Dysfunction. Manado: Medical Faculty Sam Ratulangi University, 1992.

9. Tendean OS. Infertilitas Pria. Tendean OS, editor. Pendidikan Dasar Andrologi \& Genetika. Program Pendidikan Dokter Spesialis I. Manado: FK Unsrat, 2011.

10. WHO. Guidelines on Diagnosis and Treatment of Fertility. Singapore: Singapore Press, 1994.

11. Wolf DP. Sperm-Egg Interaction in Evaluation and Treatment of Infertile Male. New York: Cambridge University Press, 1996.
12. Zarkova. Tribestan Experimental and Clinical Studies. In: Documentation Pharmacin Bulgari, 1995; p. 24-47.

13. Moeloek N. Diagnosis of the Infertile Male in Clinical Reproductive Endocrinology and Infertility. Wong PC, editor. AresSerono Colloguina, Experia Medica Asia Pasific Congress Series, 1990.

14. Tjokronegoro A. Penyebab dan Patofisiologi Infertilitas Pria. Buku acara dan kumpulan abstrak, PIT XIV PANDI dan KONAS I ASI. Jakarta: Bagian Biologi Kedokteran FKUI, 2002; p. 28-30.

15. Naegler HM, Luntz RK, Francis MG. Varicocele. In: Lipshultz LI, Howard SS, editors. Infertility in The Male (3th ed). Missouri: Mosby, 1997. 